\title{
Karakteristik Kekerasan Seksual Terhadap Perempuan di Kabupaten Nias
}

Formas Juitan Lase

Universitas Kristen Indonesia

\begin{abstract}
Abstrak: Artikel ini membahas karakteristik kekerasan seksual terhadap perempuan di Kabupaten Nias, Sumatera Utara. Data diperoleh dengan studi pustaka, observasi dan wawancara. Hasil penelitian menunjukkan jumlah kekerasan seksual dari 2009-2016 adalah tertinggi setelah kekerasan fisik. Ada empat jenis yang diidentifikasi: (1) perkosaan, (2) intimidasi seksual, (3) pemaksaan kehamilan untuk mendapat anak laki-laki, dan (4) pemaksaan penggunaan alat-alat kontrol reproduksi. Kasus perkosaan yang paling banyak ditemukan. Penanganan kasus kekerasan seksual di Kabupaten Nias masih bersifat sporadis, dan belum ada sinergi yang berarti antara pemerintah, lembaga pengada layanan dan sektor kriminal dan keadilan sipil.
\end{abstract}

Kata Kunci: Kekerasan Seksual, Perempuan, Nias, Karakteristik

Abstract: This article focuses on characteristics of sexual violence againts women in Nias Distric, North Sumatera. Data obtained by literature study, observation and interview. The results showed the number of sexual violence from 2009-2016 was the highest after physical violence. There are four types identified: (1) rape, (2) sexual intimidation, (3) coercion of pregnancy, and (4) forcible use of reproductive control devices. The most prevalent cases are rape. The handling of sexual assault cases in Nias District is still sporadic, and there is no meaningful synergy between the government, service provider institutions and the criminal and civil justice sectors.

Key Words: Sexual Violence, Women, Nias, Characteristics

Koresponden penulis:

Formas Juitan Lase, Pusat Studi Wanita, Universitas Kristen Indonesia Jl. Mayjen Sutoyo No. 2. Gedung LPPM, UKI, Cawang, Jakarta Timur.

E-mail: formas.juitan@uki.ac.id 


\section{PENDAHULUAN}

Kekerasan seksual merupakan kekerasan yang serius dalam peta kekerasan terhadap perempuan karena menimbulkan dampak yang siginifikan bagi korban yakni terkait dengan kesehatan fisik dan psikologisnya (Krug, et al. 2002, 149). Dari data Komnas Perempuan (2017) menunjukkan kekerasan seksual adalah kekerasan dengan jumlah tertinggi kedua setelah kekerasan fisik yakni 3.495 kasus pada 2016. WHO juga mengeluarkan data yang menyebutkan satu dari tiga perempuan atau 35,6 persen perempuan di dunia pernah mengalami kekerasan fisik dan/atau seksual dengan pelaku paling banyak adalah rekan intim atau orang asing (WHO 2013, 21-30).

Salah satu wilayah yang jarang muncul dalam pemetaan kasus kekerasan seksual di Indonesia adalah Pulau Nias. Seperti wilayah lainnya, masyarakat Nias juga memiliki budaya patriarki yang khas. Mereka membedakan posisi laki-laki dan perempuan dalam urusan adat maupun dalam aktivitas sehari-hari. Laki-laki cenderung ditempatkan sebagai kepala dan pengambil keputusan. Sedangkan perempuan sebagai yang membantu laki-laki dan tidak memiliki kedudukan yang berarti. Dalam urusan adat misalnya, perempuan lebih banyak berada di dalam rumah mengurus keperluan adat dan masak, sedangkan laki-laki berada di halaman rumah (gare) untuk membicarakan dan memutuskan segala hal.

Perbedaan posisi ini berimplikasi pada kehidupan perempuan baik secara fisik maupun secara psikis. Perempuan masih dilihat sebagai pelengkap laki-laki, sehingga masa depannya jarang diperhatikan. Sedangkan laki-laki menempati posisi utama dan sentral dalam masa depan keluarga. Ketika seorang perempuan menikah, maka ia bukan lagi milik keluarganya. Perempuan tersebut menjadi milik suaminya. Karena itu, 
istilah menantu dalam masyarakat Nias disebut "mböli gana'a" yang secara harafiah diterjemahkan “emas yang dibeli” (Lase 2015).

Dalam kondisi budaya masyarakat Nias yang lebih mengunggulkan laki-laki, kekerasan yang dialami perempuan digunakan pelaku sebagai bentuk dominasi, dan penghukuman terhadap perempuan yang dianggap "tidak patuh" dengan "norma" masyarakat. Dalam kasus kekerasan seksual seperti pemaksaan kehamilan misalnya, perempuan Nias dilihat sebagai orang yang pantas mendapatkan perlakuan demikian. Karena ia dilihat sebagai individu yang wajib melahirkan anak, terutama anak laki-laki sebagai penerus garis keluarga. Kalau tidak, perempuan tersebut dianggap tidak berharga. Hal ini sejalan dengan pandangan yang meyakini bahwa tujuan perempuan dan laki-laki menikah semata-mata untuk tujuan prokreasi, sehingga terikat dengan beban moral dan adat untuk menghasilkan keturunan.

Artikel ini secara khusus membahas bagaimana fenomena kekerasan seksual ini berlangsung di Kabupaten Nias. Khususnya membahas karakteristik kekerasan seksual apa yang muncul dan bagaimana kekerasan itu terjadi. Tujuan artikel ini untuk memberikan gambaran seperti apa karakteristik kekerasan seksual yang terjadi di Kabupaten Nias guna mencari strategi pemutusan rantai kekerasan setelah karakteristik masalahnya terpetakan. Karena itu, data dalam artikel ini masih berupa data awal dan tidak mengungkap secara mendalam penyebab kekerasan seksual dalam budaya masyarakat Nias.

\section{KABUPATEN NIAS}

Kabupaten Nias adalah salah satu daerah yang belum lama dimekarkan di wilayah Sumatera Utara. Pada Juli 2003, berdasarkan Lembaran Negara Republik Indonesia Tahun 2002, Kabupaten Nias dimekarkan menjadi Kabupaten Nias dan Kabupaten Nias 
Selatan. Kemudian pada Mei 2009, Kabupaten Nias kembali dimekarkan menjadi empat daerah otonom baru: Kabupaten Nias, Kabupaten Nias Utara, Kabupaten Nias Barat, dan Kota Gunungsitoli setelah disahkannya Undang-Undang Pemekaran Nias setahun sebelumnya.

Perubahan-perubahan tersebut tidak hanya berdampak secara administratif; namun juga secara sosial, di mana seharusnya pemekaran daerah ditujukan untuk meningkatkan pelayanan publik dan meningkatkan kesejahteraan masyarakat. Sehingga, pemekaran ini selayaknya juga diikuti dengan peningkatan jumlah dan kualitas pelayan publik, termasuk kepada perempuan. Akan tetapi, jumlah lembaga pemerintah pengada layanan terhadap perempuan tidak berubah semenjak tahun 2003, awal mula wilayah Nias dimekarkan. Akibatnya, P2TP2A Nias menangani seluruh kasus kekerasan terhadap perempuan yang ada di lima wilayah otonom Nias.

Penelitian sebelumnya tentang kekerasan seksual di Nias menemukan sebanyak 29 kasus pada 2006 dan 14 kasus pada 2007 (Lubis 2011, 12-13). Bentuk-bentuk kekerasan seksual yang ditemukan adalah perkosaan, pelacuran paksa, dan pelecehan seksual. Kasus perkosaan berada di urutan tertinggi sebanyak 25 kasus sepanjang dua tahun tersebut. Penelitian tersebut memilih lokasi di tiga kecamatan yakni Kecamatan Gunungsitoli, Kecamatan Sirombu, dan Kecamatan Tuhemberua yang merupakan kecamatan yang berada di Kabupaten Nias pasca-pemekaran pada 2001. Masing-masing kecamatan mewakili wilayah Kabupaten Nias dari tengah (Gunungsitoli), utara (Sirombu), dan barat (Tuhemberua).

Pada 2009, Kabupaten Nias dimekarkan lagi menjadi empat wilayah, yakni Kotamadya Gunungsitoli, Kabupaten Nias, Kabupaten Nias Barat, dan Kabupaten Nias Utara. Pemekaran tersebut tidak membawa perubahan yang signifikan dalam 
menangani kasus-kasus kekerasan terhadap perempuan di Pulau Nias. Hanya Kabupaten Nias yang memiliki lembaga P2TP2A yang juga menjangkau keseluruhan kabupaten/kota yang ada di Pulau Nias. Karena itu, lokasi penelitian ini difokuskan pada satu wilayah saja yaitu Kabupaten Nias sejak dimekarkan pada 2009 hingga 2016 saat penelitian berlangsung.

\section{KEKERASAN SEKSUAL}

Kekerasan seksual menurut WHO adalah satu dari empat jenis kekerasan lainnya yakni, kekerasan fisik, psikis dan ekonomi (Krug et al. 2002). Menurut PBB, kekerasan seksual adalah: Any sexual act, attempt to obtain a sexual act, unwanted sexual comments or advances, or acts to traffic, or otherwise directed, against a person's sexuality using coercion, by any person regardless of their relationship to the victim, in any setting, including but not limited to home and work (Krug, et al. 2002, 149). Artinya, segala tindakan yang mengarah pada tindakan seksual baik dalam bentuk verbal seperti kata-kata, komentar atau rayuan, maupun dalam bentuk nonverbal seperti tatapan mata dan lain sebagainya yang tidak diinginkan oleh seseorang dalam situasi apapun dan di manapun adalah tergolong kekerasan seksual.

Tindakan seksual berupa tatapan mata serta kata-kata dan komentar yang ditujukan kepada korban biasanya digolongkan pada kategori pelecehan seksual. Hal ini sering kali tidak dianggap sebagai bagian dari kekerasan seksual. Demikian juga hal-hal yang dianggap sudah menjadi "kodrat" perempuan seperti mengandung dan melahirkan meski dilakukan di luar dari kehendak korban jarang dianggap sebagai kekerasan seksual. Padahal, WHO (2013, 6-7) telah menyebutkan dengan jelas bahwa "being physically forced to have sexual intercourse when you did not want to, having sexual intercourse because you were afraid of what your partner might do, and/or being forced to do something sexual that you found humiliating or degrading" masuk dalam definisi 
kekerasan seksual. Salah satunya seperti kasus pemaksaan hubungan seksual agar hamil, pemaksaan aborsi, pemaksaan penggunaan kontrasepsi dan sterilisasi.

Dalam kasus pemaksaan kehamilan misalnya, dialami oleh korban perkosaan atau perempuan yang dilarang untuk menggunakan kontrasepsi sehingga terjadi kehamilan yang tidak diinginkan korban. Dalam konteks masyarakat Nias, pemaksaan kehamilan dilakukan untuk mendapatkan keturunan anak laki-laki. Ketika korban tidak mampu melahirkan anak laki-laki, korban mendapatkan penolakan, bahkan penghinaan dan perendahan diri sebagai perempuan yang tidak "subur".

Dalam klasifikasi yang dibuat oleh WHO, kekerasan seksual adalah tipologi dari kekerasan antarpribadi. Artinya, kekerasan seksual dapat berlangsung dalam dua bentuk: (1) kekerasan keluarga dan rekan intim (family and intimate partner); (2) kekerasan masyarakat (community violence) (Krug 2002, 6). Kekerasan seksual yang terjadi dalam keluarga dan rekan intim, korbannya bisa anak, istri atau suami dan orang yang lebih tua. Sedangkan pelakunya bisa ayah kandung, ibu kandung; ayah tiri; ibu tiri, kakek, nenek. Khusus untuk rekan intim pelakunya bisa suami atau istri. Sedangkan kekerasan seksual yang dilakukan masyarakat, korbannya bisa siapa saja: anak-anak, perempuan, laki-laki. Sementara pelakunya ada dua kategori, bisa kenalan (acquintance) dan bisa juga orang asing (stranger). Untuk kategori kenalan, pelakunya bisa pacar atau bisa juga tetangga; sedangkan untuk orang asing, bisa siapapun yang tidak memiliki relasi personal dengan korban.

Korban yang mengalami kekerasan seksual juga mengalami dampak yang tidak kecil, terutama berkaitan dengan kesehatan fisik dan psikologis korban (Krug, et al. 2002, 149; WHO 2013, 13). Kesehatan fisik yang dimaksud berkaitan dengan kesehatan seksual dan reproduksi korban. Fisik korban juga dapat mengalami trauma, misalnya 
dalam kasus perkosaan, maka bagian tubuh korban yang menjadi sasaran kekerasan dapat mengalami trauma atau disebut juga dengan istilah genital trauma (WHO 2013, 8). Sedangkan kesehatan psikologis korban yakni terguncangnya jiwa korban berkaitan dengan tindakan tidak diinginkan yang menimpa dirinya. Gangguan psikologis juga dapat terjadi selain karena trauma atau stres, juga dapat terjadi karena korban berada di bawah kontrol pelaku serta menimbulkan ketakutan.

\section{METODE DAN DATA}

Data yang dipaparkan dalam artikel ini diperoleh berdasarkan pendekatan pemetaan sosial dengan metode pengumpulan data menggunakan studi pustaka, observasi dan wawancara (Suharto tanpa tahun). Kasus-kasus kekerasan seksual secara sporadis diketahui banyak terjadi di Kabupaten Nias, namun tidak ada sumber data utama yang valid yang bisa dirujuk. Hal ini disebabkan karena laporan dan penanganan kekerasan seksual tersebar ke beberapa lembaga pengada layanan dan lembaga di sektor keadilan sipil dan kriminal. Oleh karena itu, peneliti menggunakan metode studi pustaka dengan mendatangi satu per satu lembaga terkait.

Setelah mengkalkulasi data-data kasus yang ditangani dan diproses, peneliti menyadari jika data-data ini bersifat seperti fenomena gunung es. Kita tidak pernah tahu apa yang sebenarnya terjadi di lapangan. Apakah ada kemungkinan jumlah kekerasan di masing-masing kecamatan jauh lebih banyak atau lebih sedikit dari tahun ke tahun? Apakah mungkin ada jenis kekerasan seksual lain yang selama ini terjadi, namun tidak pernah dilaporkan kepada pihak terkait? Hal-hal ini yang kemudian mendorong peneliti menggunakan metode observasi dan wawancara kepada informandi sekitar lokasi penelitian dan mengetahui kondisi warga secara dekat. Peneliti melakukan wawancara dan observasi kepada sejumlah tokoh masyarakat lokal baik di 
pemerintahan, agama maupun tenaga kesehatan di setiap kecamatan untuk memeroleh data yang dibutuhkan.

Teknik pemilihan informan menggunakan metode snowball sampling, yakni memilih informan berdasarkan kemudahan terkait fenomena persoalan yang tengah mengemuka dan menulusuri informan lainnya sesuai informasi dari informan terkait (Babbie 2014, 200-201). Peneliti juga melakukan wawancara kepada koordinator lembaga pelayanan perempuan seperti PKPA dan Pesada yang menangani kekerasan seksual untuk mengetahui proses dan penanganan kasus selama ini.

Data yang diperoleh dari ketiga metode tersebut dikompilasi, sekaligus juga dilakukan pengecekan untuk menghindari perhitungan ganda jika ditemukan kasus yang sama. Data yang dikumpulkan dari metode studi pustaka selanjutnya disebut data sekunder, dan data dari hasil observasi dan wawancara disebut sebagai data primer. Tim peneliti telah memastikan wilayah kerja dari masing-masing sumber data (via pesan singkat berbasis online, wawancara dan observasi) agar tidak terjadi overlapping.

Selanjutnya hasil kompilasi data akhir tersebut disajikan dalam bentuk tabel dan grafik dengan menggunakan alat analisis kuantitatif seperti Excel ataupun Googlesheets. Hasil angka tersebut kemudian diinterpretasikan untuk menjawab pertanyaan penelitian. Metode analisis yang digunakan adalah kualitatif deskriptif yang dipakai untuk menggambarkan kekerasan seksual terhadap perempuan beserta karakteristiknya. Analisis deskriptif ini mendukung pengolahan data kuantitatif dari seluruh kasus kekerasan seksual terhadap perempuan di Kabupaten Nias.

Oleh karena pengambilan data dilakukan pada akhir Oktober hingga awal November 2016, maka perlu menjadi catatan di sini bahwa data tahun 2016 yang 
diperoleh terbatas hingga Oktober 2016. Sedangkan data kasus yang terjadi pada November dan Desember 2016 tidak terhitung dalam uraian berikut.

\section{HASIL DAN PEMBAHASAN}

Temuan menunjukkan jumlah kekerasan seksual di Kabupaten Nias dari tahun 20092016 bersifat fluktuatif sebanyak 65 kasus. Jumlah yang teridentifikasi berdasarkan data primer jauh lebih besar dibandingkan data sekunder yakni 31 kasus, dan 34 kasus dari data primer. Sumber data sekunder diperoleh dari lembaga pengada layanan dan sektor kriminal dan keadilan sipil.

Tabel 1. Data kekerasan seksual di Kabupaten Nias, 2009-2015

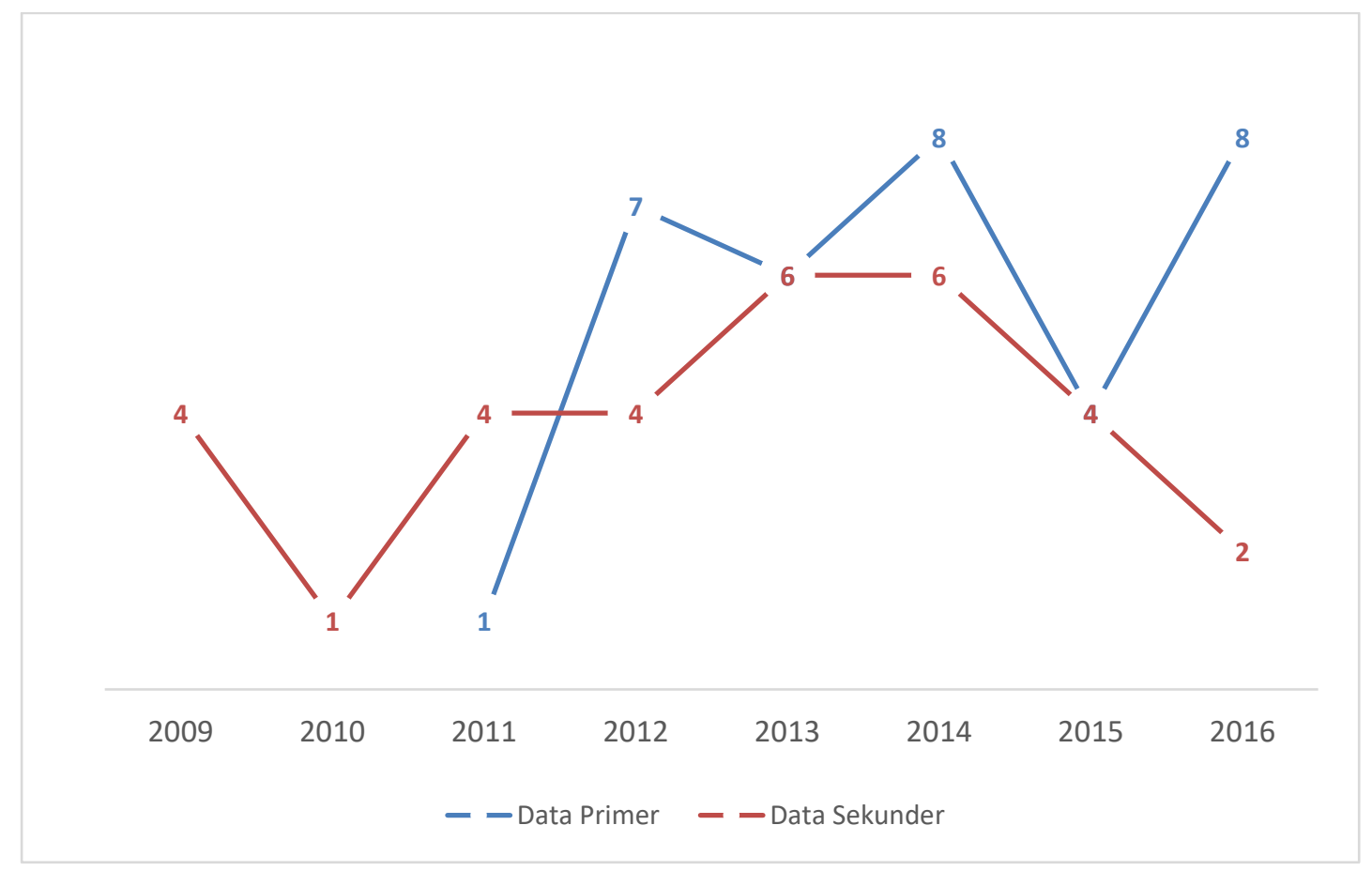

Sumber: Hasil penelitian

Lembaga pengada layanan pertama yang ditemui tim peneliti adalah P2TP2A. Secara institusi, lembaga ini punya peran yang sentral dalam penanganan kasus kekerasan terhadap perempuan. Salah satu peran yang diemban lembaga ini adalah sebagai pusat data dan informasi kasus kekerasan terhadap perempuan dewasa maupun di bawah 
umur. Namun, peran ini tidak selalu berjalan mulus karena disebabkan keterbatasan sumber daya manusia. Sejak dimekarkan tahun 2003, jumlah lembaga pengada layanan tidak berubah, akibatnya P2TP2A yang ada di Kabupaten Nias menangani seluruh kasus kekerasan terhadap perempuan yang ada di lima wilayah otonom Nias.

Beruntung, pasca-gempa Nias pada Maret 2005, banyak lembaga swadaya masyarakat baik dari dalam maupun luar negeri datang ke Pulau Nias. Keberadaan sejumlah LSM-LSM seperti PKPA Nias, Caritas Keuskupan Sibolga, Pesada Nias, World Vision, dan seterusnya telah mendorong adanya pencatatan terhadap laporan kasus kekerasan di Kabupaten Nias dan Pulau Nias secara umum. Namun demikian, hingga kini tersisa dua lembaga pengada layanan yakni PKPA Nias dan Pesada Nias yang masih melakukan penanganan kekerasan terhadap perempuan dan upaya-upaya pengarusutamaan gender dalam masyarakat Nias. Sementara, Caritas Keuskupan Sibolga sejak 2009 sudah tidak memfokuskan penanganan isu gender ini dalam unit khusus; melainkan meleburkan penanganan isu tersebut ke semua unit dan program mereka.

Selanjutnya, sumber data sekunder dari sektor kriminal dan keadilan sipil diperoleh dari Pengadilan Negeri Gunungsitoli, Pengadilan Agama Gunungsitoli, dan Unit Perlindungan Perempuan dan Anak (UPPA) Polres Nias. Pengadilan Negeri Gunungsitoli menyumbang data yang cukup lengkap dari tahun ke tahun. Ketika tim menyambangi kantor Pengadilan Negeri Gunungsitoli, tidak ditemukan kendala yang berarti dalam mengakses data. Peneliti mencari, mendata dan memverifikasi data dari arsip pengadilan selama empat hari berturut-turut. Temuan data menunjukkan kekerasan seksual dicatat dengan jelas. Kasus kekerasan seksual umumnya diselesaikan hingga pelaku divonis penjara. Sementara Pengadilan Agama Gunungsitoli tidak 
menyumbang data kekerasan seksual sama sekali. Dari keterangan pegawai Pengadilan Agama tersebut, data tersedia hanya data perceraian yang umumnya disebabkan karena persoalan ekonomi dan bukan kekerasan seksual (Wawancara, Selasa 24 Oktober 2016).

Sedikit berbeda dengan UPPA Polres Nias, kendala yang mengemuka saat tim mendatangi adalah tidak adanya pegawai yang dapat dihubungi. Beberapa kali tim menghubungi kontak pimpinan unit, namun tidak direspon. Setelah dikunjungi ketiga kalinya, tim baru berhasil menjumpai koordinator UPPA Polres Nias dan memberikan akses kepada peneliti untuk menghimpun data. Sayangnya, hanya sedikit data kekerasan seksual yang diperoleh dari sini. Baik Pengadilan Negeri Gunungsitoli, Pengadilan Agama Gunungsitoli maupun UPPA Polres Nias terbatas dalam mencatat jenis kekerasan seksual, yakni hanya perkosaan dan intimidasi seksual.

Gambaran kekerasan seksual yang diperoleh dari lembaga-lembaga tersebut masih sangat rapuh dan tidak mencukupi. Di sisi lain, lembaga pengada layanan yang bersifat swadaya masyarakat pun mengalami kondisi serupa: satu lembaga untuk satu Pulau Nias, dengan jumlah sumber daya manusia yang sama terbatasnya. Hal ini semakin mendorong peneliti untuk mengambil data primer di luar data yang telah dikumpulkan oleh lembaga pemerintah dan swadaya masyarakat.

Peneliti kemudian mencari informan di setiap kecamatan yang bersedia dan tidak menganggap tabu membagikan kondisi ataupun kasus-kasus kekerasan seksual terhadap perempuan yang pernah terjadi di daerah tempat tinggalnya. Ada 10 kecamatan yang didatangi tim peneliti yakni Botomuzöi, Gidö, Hiliduho, Idanögawo, Ulugawo, Bawölato, Sogae'adu, Hiliserangkai, Somölö-mölö, dan Ma’u. Jumlah informan dari masing-masing kecamatan juga bervariasi. Mereka yang bersedia membagikan informasi ini melakukan hal yang cukup berani dengan harapan agar kondisi 
perempuan di tempat tinggal mereka dapat berubah sekalipun anggota keluarga mereka yang seringkali ikut hadir di saat peneliti mewawancarai informan tampak tidak setuju dan bahkan ada yang melarang untuk berbicara lebih banyak kepada peneliti.

Data primer yang dihimpun oleh peneliti tersebut menunjukkan bahwa kasuskasus kekerasan antarpribadi terhadap perempuan di sepuluh kecamatan tersebut tidak pernah diajukan ke ranah hukum. Hampir seluruh informan penelitian menganggap kasus kekerasan terhadap perempuan adalah hal yang tabu dibicarakan dan menolak membagikan informasi. Tokoh masyarakat yang dilibatkan oleh korban ataupun keluarga korban dalam menangani kasus-kasus tersebut adalah pemerintah desa, warga setempat termasuk di dalamnya tokoh-tokoh adat, dan yang paling banyak menerima laporan korban adalah tokoh rohani dari gereja setempat. Berdasarkan keterlibatan tokoh masyarakat tersebut dalam menangani kekerasan yang dialami korban, peneliti memilih beberapa informan yang berasal dari berbagai latar belakang yang berbeda, yakni: (1) pendeta jemaat dan pasangan, guru jemaat dan pasangan (gereja), (2) bidan dan perawat desa (Puskesmas), (3) kepala desa dan ibu PKK tingkat desa (pemerintahan desa), (4) warga desa.

\section{KARAKTERISTIK KEKERASAN SEKSUAL DI KABUPATEN NIAS}

Bentuk-bentuk kekerasan seksual yang dialami perempuan di Kabupaten Nias adalah perkosaan, intimidasi seksual, pemaksaan kehamilan, dan pemaksaan penggunaan alatalat kontrol reproduksi. Temuan ini sedikit berbeda dari penelitian yang dilakukan oleh Lubis (2011). Selain kasus perkosaan dan pelecehan seksual, Lubis juga menemukan kasus pelacuran paksa yang dalam penelitian ini tidak ditemukan. Sebaliknya, penelitian ini menemukan karakteristik lain, yakni: pemaksaan kehamilan dan 
sterilisasi. Berdasarkan hasil tabulasi, kasus perkosaan merupakan kasus kekerasan seksual paling banyak dialami oleh perempuan sebanyak 48 kasus. Diikuti oleh pemaksaan kehamilan 15 kasus, intimidasi seksual 1 kasus, dan pemaksaan sterilisasi 1 kasus.

\section{Perkosaan}

Kasus perkosaan di Kabupaten Nias paling banyak dialami oleh perempuan di bawah umur sebanyak 30 kasus. Kasus-kasus perkosaan terjadi dalam kerangka hubungan berpacaran. Salah seorang informan dari gereja mengungkapkan beberapa penyebab terjadinya perkosaan dalam hubungan berpacaran: pertama, ketiadaan pengetahuan tentang pendidikan seksual, penggunaan teknologi komunikasi yang tidak dapat dikontrol oleh orang tua, dan tipu daya serta iming-iming dari pelaku (hasil wawancara, 25 Oktober 2016). Para pelaku adalah orang-orang yang mengenal korban dari dekat: ayah kandung, ayah tiri, paman, abang ipar, tetangga dan paling banyak adalah pacar.

Informan menjelaskan bahwa pendidikan seksual hampir tidak pernah diberikan kepada anak, baik dari orangtua maupun guru di sekolah (Wawancara, 27 Oktober 2016). Kalaupun dibicarakan di sekolah oleh guru Biologi, pelajaran tersebut sangatlah terbatas dalam membahas perilaku seksual. Seks merupakan kata yang tabu dibicarakan apalagi diajarkan pada anak. Banyak remaja yang kemudian mencari tahu sendiri tubuh dan fungsi reproduksinya dari teman. Ketidaktahuan ini yang paling banyak membuat pasangan remaja coba-coba, terutama remaja di desa-desa yang jauh dari akses informasi. 
Tabel 3. Pelaku Kekerasan Seksual di Kabupaten Nias 2009-2016

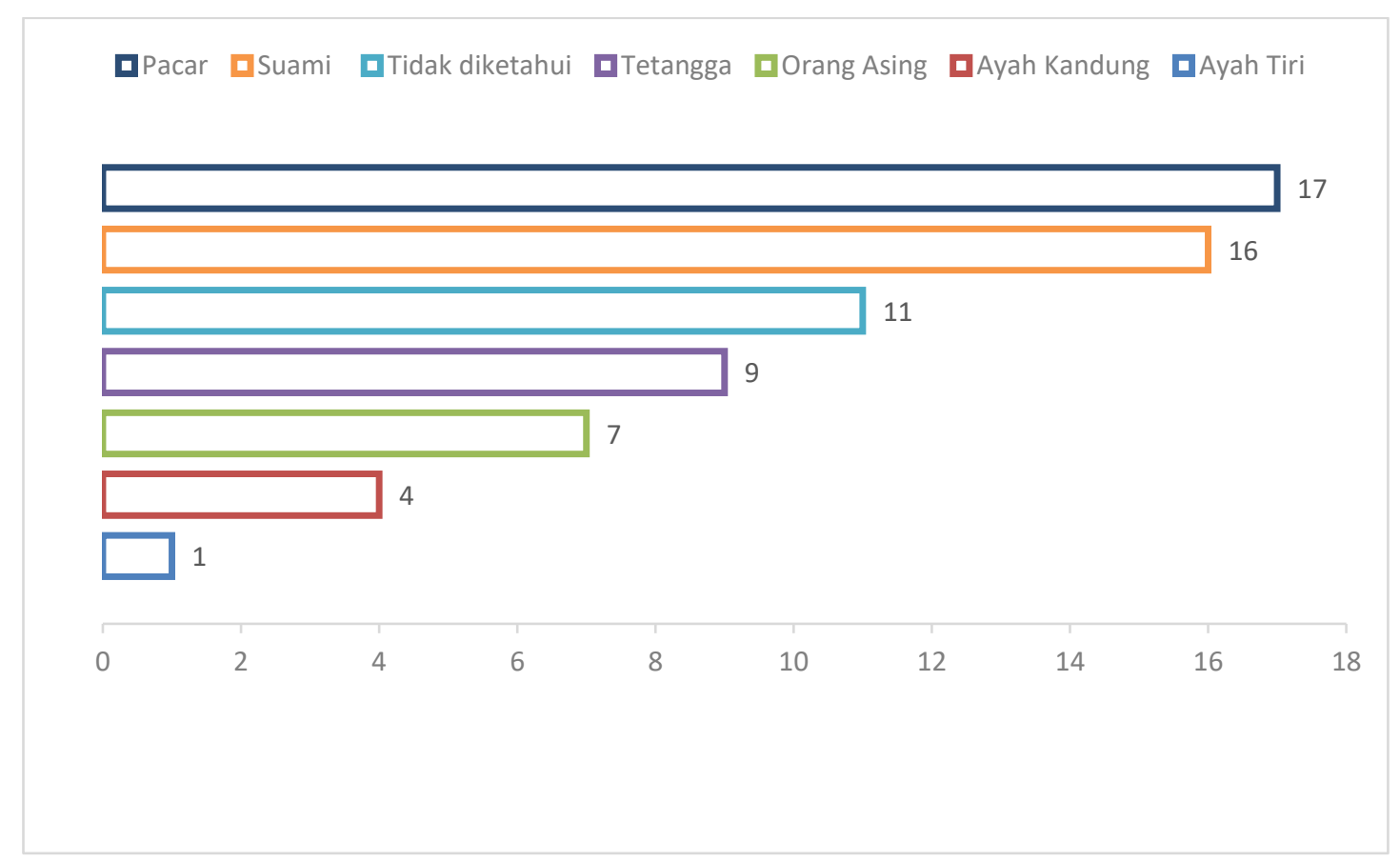

Sumber: hasil Penelitian

Di sisi lain, meningkatnya penggunaan telepon genggam hingga ke desa-desa membuat banyak remaja gandrung membangun interaksi dengan orang lain yang dikenalnya lewat media sosial. Salah seorang informan pendeta dari Kecamatan Ulugawo menyebutkan beberapa kasus yang ditanganinya berawal dari kenalan di media sosial Facebook, kemudian mereka sepakat bertemu di suatu tempat dan berujung pada perkosaan. Mirisnya, korban tidak mengenal betul si pelaku, sehingga sulit diidentifikasi dan dilaporkan kepada pihak berwajib. Untuk menghindari malu, keluarga kemudian menikahkan korban secara paksa kepada laki-laki lain dengan/tanpa persetujuan korban.

Untuk kasus-kasus perkosaan yang dialami oleh perempuan dewasa, biasanya berlangsung dalam beberapa situasi. Jika dicermati berdasarkan sumber data sekunder, ada tiga kasus dari 31 kasus perkosaan yang dialami perempuan dewasa. Pertama, kasus perkosaan yang pelakunya adalah ayah tiri korban, terjadi di Kecamatan 
Hiliserangkai tahun 2013, dan belum ada putusan pengadilan kepada pelaku. Kedua, kasus perkosaan yang pelakunya orang lain (tidak diketahui hubungannya dengan korban) di Kecamatan Somölö-mölö tahun 2015, dan pelakunya dihukum 2 tahun penjara.

Kasus ketiga adalah kasus pemerkosaan berkelompok (gang rape) dengan jumlah pelaku sebanyak 4 orang. Kasus ini terjadi di Kecamatan Sogae'adu pada 2011. Berdasarkan sumber data dari Pengadilan Negeri Gunungsitoli, para pelaku telah dijatuhi hukuman 8 tahun penjara. Kendati demikian, tidak ada data yang ditemukan bagaimana keberlangsungan penanganan dan pemulihan korban. Hingga saat ini belum ada mekanisme yang tersedia terkait penanganan para korban usai kasus mereka berakhir. Terutama bagi para korban yang tidak didampingi oleh lembaga pengada layanan seperti PKPA Nias atau Pesada Nias.

Sedangkan yang bersumber dari data primer, kasus perkosaan yang dialami perempuan dewasa dominan dilakukan oleh pacar sebanyak delapan kasus. Kasus berikutnya dilakukan oleh ayah kandung dan tetangga. Salah satu kasus perkosaan yang pelakunya adalah pacar terjadi tahun 2016 di Kecamatan Idanögawo. Pelaku kemudian melarikan diri keluar daerah sebelum keluarga berhasil "bermusyawarah" untuk menyelesaikan masalah tersebut. Seluruh kasus yang diperoleh dari data primer tidak pernah dilaporkan oleh korban atau keluarga korban kepada pihak berwajib.

\section{Intimidasi Seksual}

Selanjutnya, tercatat satu kasus dengan jenis intimidasi seksual yang diperoleh juga dalam penelitian ini. Intimidasi seksual menurut definisi Kompas Perempuan $(2014,5)$ berupa ancaman atau percobaan perkosaan yang ditujukan kepada perempuan baik secara langsung maupun melalui medium tertentu, sehingga 
menimbulkan ketakutan dan gangguan psikologis pada korban. Kasus ini terjadi tahun 2011 di Kecamatan Gidö, dan korbannya adalah anak di bawah umur. Hal yang menarik adalah kasus intimidasi seksual ini diperoleh dari data Pengadilan Negeri Gunungsitoli. Ini artinya, warga telah berani melaporkan kejadian tersebut sebagai bagian dari kejahatan dan tidak ditutupi. Upaya keluarga korban melaporkan pelaku dapat dinilai selain sebagai tindakan preventif, juga sebagai gambaran bahwa telah ada kesadaran akan kekerasan seksual di lingkungannya. Karena data ini diperoleh dari Pengadilan Negeri Gunungsitoli, maka proses penanganannya dianggap berakhir setelah pelaku dijatuhi hukuman penjara dan denda. Namun sayangnya, penanganan lebih lanjut kepada korban tidak ada.

\section{Pemaksaan Kehamilan}

Salah satu alasan mengapa penelitian ini menggunakan metode observasi dan wawancara kepada para informan yang menangani atau bersentuhan langsung dengan kasus-kasus kekerasan seksual kepada korban adalah untuk menemukan karakteristik kekerasan seksual yang tidak ditemukan pada data formal lembaga layanan. Salah satunya adalah temuan kasus pemaksaan kehamilan. Menurut Komnas Perempuan (2014, 13) pemaksaan kehamilan cenderung terjadi pada dua jenis kasus: (1) perempuan korban perkosaan yang dipaksa melanjutkan kehamilannya dan melahirkan anak yang dikandungnya; dan (2) suami menghalangi istri menggunakan kontrasepsi sehingga jarak kehamilan menjadi terganggu.

Pada kasus perempuan di Kabupaten Nias, pemaksaan kehamilan yang ditemukan bukan dialami oleh korban perkosaan, sebagaimana umum ditemukan; namun ada kemungkinan suami melarang si istri menggunakan kontrasepsi. Karena tujuan pemaksaan kehamilan di sini adalah untuk mendapatkan anak laki-laki. 
Perempuan dipaksa mengandung dan melahirkan anak laki-laki, meski telah melahirkan anak perempuan dalam jumlah yang banyak sekalipun. Anak laki-laki dianggap sebagai penerus trah keluarga yang sah dibandingkan anak perempuan. Ketika seorang perempuan tidak mampu melahirkan anak laki-laki, derajat perempuan di mata suami, keluarga dan lingkungannya, rendah. Kondisi ini menimbulkan rasa rendah diri bagi perempuan karena merasa gagal menjadi 'istri' yang berguna bagi suami dan keluarga. Tidak sedikit juga para korban mengalami kekerasan psikis dan berpotensi mengalami kekerasan fisik dan ekonomi dengan cara penelantaran.

Menurut bidan desa yang menjadi informan penelitian ini, korban yang umum mengalami pemaksaan kehamilan adalah ibu-ibu yang berusia 40 tahun ke atas. Artinya, pemaksaan kehamilan dialami oleh perempuan yang bukan dalam kondisi ideal dan produktif melahirkan. Secara kesehatan, hal ini sangat berisiko pada kesehatan dan keselamatan perempuan. Bukan tidak mungkin kasus pemaksaan kehamilan ini berujung pada kematian si ibu (WHO 2013, 13). Apalagi diperparah oleh ketiadaan tenaga kesehatan yang menetap di desa-desa, sehingga para ibu lebih banyak bergantung pada dukun atau melahirkan sendirian.

\section{Pemaksaan Kontrasepsi dan Sterilisasi}

Sama dengan kasus pemaksaan kehamilan, kasus pemaksaan kontrasepsi dan sterilisasi juga diperoleh dari metode wawancara. Artinya, kasus ini tidak ditemukan dari data sekunder karena tidak pernah dilaporkan sebagai kejahatan terhadap perempuan. Pemaksaan kontrasepsi dan sterilisasi berlangsung tanpa persetujuan korban atau bisa juga karena ketidaktahuan korban sehingga memberikan persetujuan (Komnas Perempuan 2014, 10). Pada kasus di Kabupaten Nias, korban yang ditemukan berasal dari kecamatan Somölö-mölö. Kecamatan ini cukup jauh dari pusat kota. 
Peneliti membutuhkan waktu tiga jam perjalanan dengan kondisi jalan yang rusak parah untuk menjangkau wilayah tersebut.

Informan yang ditemui menyebutkan bahwa korban pemaksaan kontrasepsi dan sterilisasi tidak memiliki pengetahuan yang memadai terhadap kontrasepsi dan sterilisasi. Ia dipaksa oleh suaminya untuk tidak boleh memiliki anak lagi. Dalam kondisi ini, korban juga berpotensi mengalami kekerasan fisik, psikis, dan ketakutan karena di bawah kontrol dan ancaman pelaku secara bersamaan. Namun, sekali lagi apa yang dialami korban tidak dipandang sebagai bagian dari kekerasan seksual bahkan oleh tenaga kesehatan sendiri yang memberikan data tersebut kepada tim peneliti.

Tabel 2. Jumlah kasus kekerasan seksual berdasarkan kecamatan

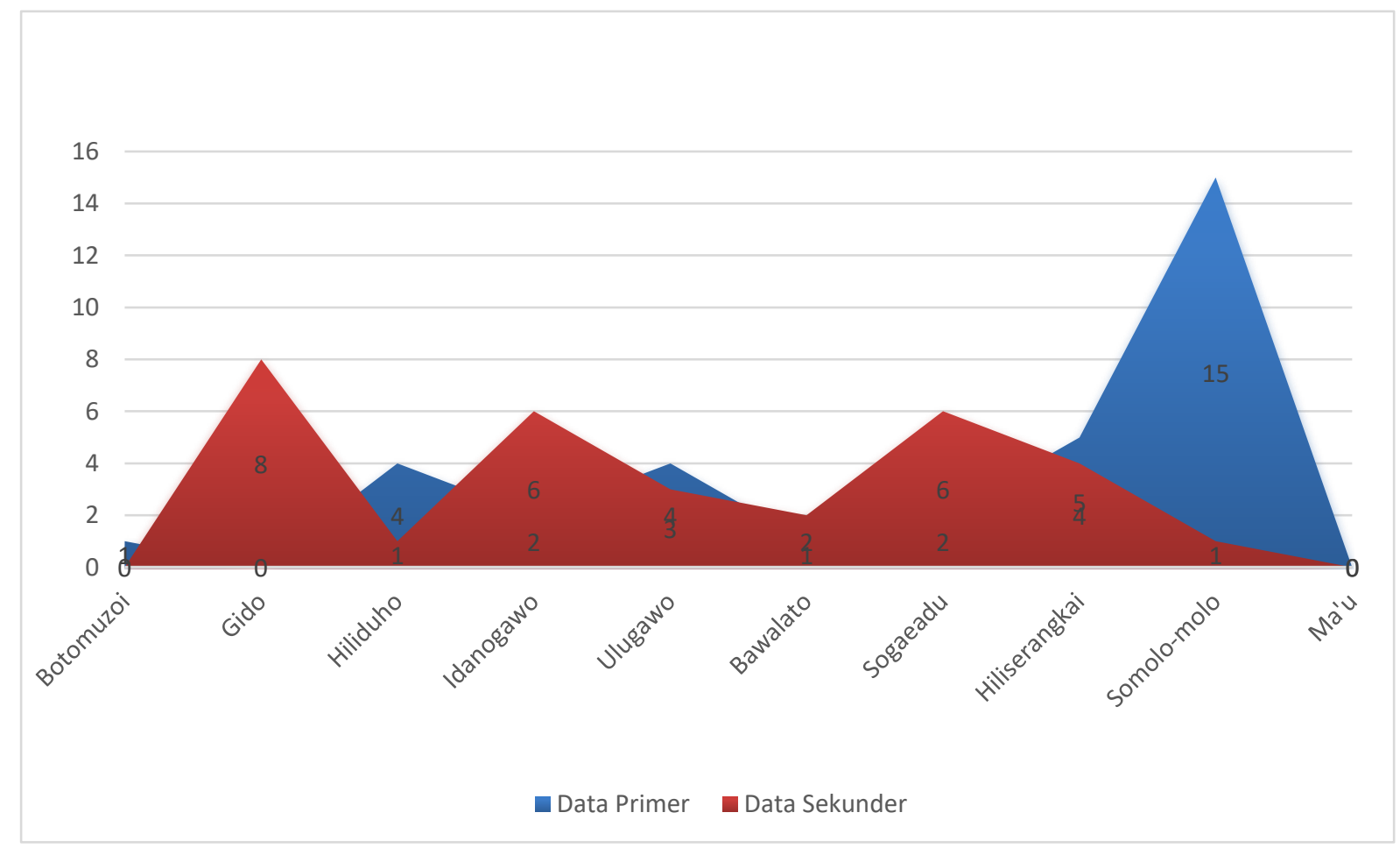

Sumber: Hasil penelitian 


\section{PELAKU MENIKAHI KORBAN: MASALAH SELESAI?}

Salah satu "solusi" penyelesaian kasus kekerasan seksual yang marak terjadi dan dianggap wajar di Kabupaten Nias adalah menikahkan korban dengan pelakunya. Ungkapan seperti sökhi mate moroi aila (lebih baik mati daripada malu) semakin meneguhkan bagaimana masyarakat Nias memandang kekerasan seksual sebagai tabu atau aib keluarga. Perceraian pun dianggap tabu, sehingga baik kasus yang berakhir dengan perceraian ataupun lari keluar daerah jumlahnya sangat kecil. Kasus-kasus kekerasan seksual yang tidak ditangani oleh lembaga pengada layanan maupun sektor kriminal dan keadilan sipil, lebih banyak diselesaikan secara "damai dan kekeluargaan" yakni dengan cara dinikahkan dengan pelaku. Pacar adalah pelaku paling banyak melakukan kekerasan seksual yakni perkosaan, dan sebagian besar korbannya adalah anak di bawah umur.

Tabel 1.2 Penyelesaian Kasus Kekerasan Seksual di Kabupaten Nias 2009-2016

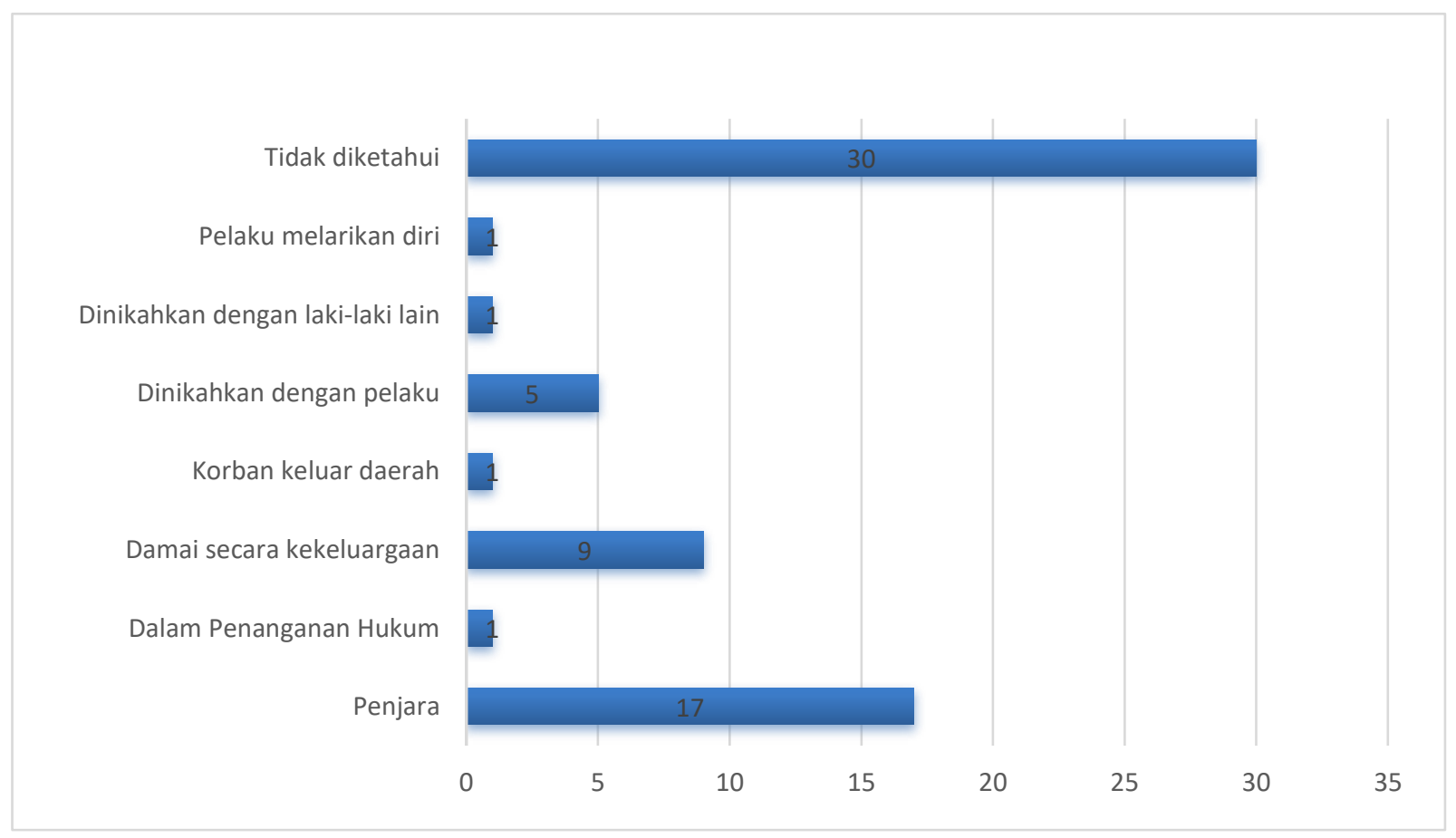

Sumber: Hasil penelitian 
Kasus-kasus yang belum ada penyelesaiannya atau tidak diketahui penyelesaiannya dominan ditemukan. Ini mengonfirmasi rendahnya kesadaran masyarakat akan isu kekerasan seksual, khususnya terhadap perempuan. Oleh karena kasus semacam ini umumnya merupakan hal tabu, maka tidak ada upaya-upaya dari luar pihak korban yang berinisiatif untuk terlibat dalam penyelesaian kasus kekerasan jika mereka mengetahui terjadinya kasus kekerasan di sekitar mereka. Raut keprihatinan akan belum adanya upaya penyelesaian atau kepedulian terhadap kasus-kasus kekerasan seksual hanya muncul pada informan-informan yang berpendidikan dan sadar akan praktik kekerasan.

\section{DISKUSI: KEKERASAN SEKSUAL DALAM MASYARAKAT NIAS}

Perempuan dalam masyarakat Nias dipandang secara dualisme. Di satu sisi perempuan ditempatkan sebagai sosok yang diagungkan, dijaga, dihormati, dan di sisi lain menjadi obyek berlangsungnya dominasi dan pertarungan kekuasaan laki-laki. Perempuan menjadi tolak ukur derajat kehormatan sebuah keluarga atau kampung. Karena itu, jika perempuannya "cacat" karena telah diperkosa atau berzinah, maka keluarga dan kampungnya ikut menanggung malu. Bahkan dalam banyak peristiwa konflik antarkampung terjadi karena perempuannya dilecehkan oleh laki-laki dari kampung lain. Namun demikian, ketika seorang perempuan yang masih "suci" menikah, maka ia diperlakukan seagung dan setinggi mungkin, salah satunya dengan proses menandu pengantin perempuan pada acara pesta pernikahan adat.

Pengagungan dan penghormatan itu tidak berlangsung sepanjang waktu. Dalam praktik kehidupan sehari-hari, posisi perempuan secara jelas dibedakan dengan lakilaki. Perempuan yang bersuami dianggap telah menjadi "hak milik" sang suami. Hal ini utamanya didorong oleh böwö (mahar) yang diberikan oleh pihak laki-laki kepada 
pihak perempuan saat pernikahan. Dari sinilah istilah "böli gana'a" dimaknai oleh masyarakat sebagai "barang belian". Kendati banyak yang menolak definisi literer tersebut, namun pada praktiknya perempuan tidak memiliki hak yang sama ketika ia keluar dari rumahnya dan tetap dibedakan ketika ia tiba di rumah suaminya. Sehingga, lahirlah ungkapan ndra'alawe nisaogö töla högö (perempuan yang dibawa masuk ke rumah).

Konsekuensi dari prosesi adat ini, membuat laki-laki (dan juga keluarga laki-laki) memiliki kekuasaan dan hak untuk mengontrol si istri. Sehingga mensahkan dominasi laki-laki terhadap perempuan dalam institusi perkawinan. Dalam kondisi tersebut, lakilaki leluasa untuk mendominasi, menguasai dan melakukan kekerasan tanpa mendapat perlawanan yang berarti dari perempuan karena dituntut oleh adat untuk patuh terhadap suami dan keluarga suami pada khususnya.

Selanjutnya, dalam upaya penanganan kasus, ada indikasi dari jumlah data kekerasan seksual di Kabupaten Nias telah dilakukan oleh lembaga pengada layanan, dan sektor kriminal dan keadilan sipil. Namun, data tersebut juga menunjukkan fakta yang lain bahwa kerja sama intersektoral dalam penanganan kasus kekerasan terhadap perempuan di Kabupaten Nias belum berjalan. Lembaga seperti P2TP2A Kabupaten Nias yang seyogianya berperan aktif dalam penanganan kasus misalnya justru lebih banyak melimpahkan kasus-kasus tersebut ke lembaga swadaya masyarakat seperti PKPA Nias dan Pesada Nias.

Sedangkan UPPA Polres Nias di sisi lain menuai kegagalan karena ketidakpercayaan korban dan keluarga korban pada umumnya terhadap sistem kerja personilnya. Sistem yang dimaksud di sini adalah sistem penanganan kasus korban yang cenderung tidak efesien dan berbelit-belit terkait administrasi. Menurut Direktur PKPA 
Nias, Khairuldani, banyak kasus kekerasan yang akhirnya tidak dilaporkan ke kepolisian karena diselesaikan secara "damai” (Wawancara, Kamis, 27 Oktober 2016). Ada dua hal yang menyebabkan masyarakat memilih menyelesaikan kasus secara damai: (1) Polisi di beberapa daerah cenderung memanfaatkan situasi korban dan mereviktimisasi (revictimization) korban; (2) Keluarga korban lebih memilih menyembunyikan kekerasan terhadap perempuan untuk menghindari aib. Bukan rahasia lagi jika terdapat oknum-oknum polisi yang memanfaatkan kasus korban untuk mendapatkan keuntungan materi dari keluarga korban atau keluarga pelaku. Hal-hal ini yang menyebabkan korban maupun keluarga korban enggan untuk melaporkan kasus kekerasan yang dialami kepada pihak kepolisian.

Dari hasil wawancara dan data yang diperoleh dari para informan, peneliti menemukan bahwa peran serta masyarakat maupun lembaga pemerintah maupun nonpemerintah yang ada di tingkat desa dapat dilibatkan sebagai mitra kerja strategis untuk memutus mata rantai kekerasan seksual di akar rumput. Hal ini didorong oleh keberadaan pihak-pihak ini di lingkungan masyarakat. Salah satu contohnya adalah keberadaan lembaga gereja. Hampir setiap desa ada gereja, baik Protestan maupun Katolik, yang dapat dirangkul untuk menjadi perpanjangan tangan penanganan kasus kekerasan yang dialami jemaatnya. Namun demikian, tidak bisa dipungkiri juga bahwa masih banyak informan, baik kalangan gereja, pemerintah desa dan puskesmas, yang tertutup terhadap isu kekerasan seksual. Karena itu, lembaga P2TP2A Nias perlu didorong untuk aktif melakukan sosialisasi literasi gender di lembaga-lembaga tersebut. 


\section{PENUTUP}

Kasus kekerasan seksual yang terjadi terhadap perempuan di Kabupaten Nias ini masih seperti fenomena gunung es. Artinya, penelitian ini belum mampu menyingkap jumlah yang sebenarnya yang diyakini jauh lebih tinggi angkanya dari apa yang sudah dipaparkan dalam penelitian ini, termasuk karakteristik lainnya yang berpeluang dialami perempuan di Kabupaten Nias. Akan tetapi, kasus-kasus tersebut tidak ditemukan dengan metode yang telah digunakan. Kendati begitu, penelitian ini memberikan sedikit gambaran apa yang selama ini terjadi di masyarakat melalui datadata sekunder dan dengan mendatangi kecamatan per kecamatan untuk mengetahui apa yang tidak dilaporkan ke lembaga pengada layanan dan sektor keadilan sipil dan kriminal. Hasilnya menunjukkan karakteristik pemaksaan kehamilan dan pemaksaan sterilisasi tidak pernah dilaporkan karena belum masuk sebagai delik aduan. Sementara, banyak perempuan menjadi korbannya.

Di sisi lain, penanganan kasus kekerasan seksual di Kabupaten Nias masih bersifat sporadis dan belum ada sinergi yang berarti antara pemerintah, lembaga pengada layanan serta sektor kriminal dan keadilan sipil. Perlu upaya sinergi yang sistematis termasuk merangkul komunitas gereja, pemerintah desa dan puskesmas setempat. Selain paling banyak menyumbang data primer, lembaga ini dilihat berpeluang menjadi mitra stretagis dalam menyediakan data, sarana pemulihan bagi korban, rekonsiliasi bagi korban dan pelaku, hingga penyadaran dalam jumlah besar oleh karena memiliki jangkauan yang lebih luas dan dekat dengan masyarakat yang ada di lingkungan lembaganya. 


\section{Catatan:}

Peneliti mengucapkan terima kasih kepada Universitas Kristen Indonesia yang telah mendukung berjalannya penelitian ini. Juga kepada Pemerintah Kabupaten Nias yang telah mengizinkan dan mendukung penuh pelaksanaan penelitian selama di Kabupaten Nias. Terakhir, kepada tim peneliti lainnya, Mita Yesyca dan Nenny Anggraini, yang telah mewujudkan dan mendukung sebagian dari hasil penelitian kami dipublikasi dalam artikel ini.

\section{REFERENSI}

Babbie, Earl. 2014. The Basic of Social Research. Sixth edition. Belmont, CA: Wadsworth, Cengage Learning.

Komisi Nasional Anti Kekerasan terhadap Perempuan. 2016. "Kekerasan terhadap Perempuan Meluas: Negara Urgen Hadir Hentikan Kekerasan terhadap Perempuan di ranah Domestik, Komunitas, dan Negara". Catatan Tahunan tentang Kekerasan terhadap Perempuan, Jakarta, 7 Maret.

Komnas Perempuan. 2014. "Bentuk-bentuk Kekerasan Seksual". Diakses 30 November 2016 dari: http://www.komnasperempuan.go.id/wpcontent/uploads/2014/12/15-Bentuk-Kekerasan-Seksual1.pdf

Kleinman, Arthur. 2000. "The Violences of Everyday Life: The Multiple Forms and Dynamics of Social Violence" dalam V. Das, A. Kleinman, P. Ramphele dan P. Reynolds (ed) Violence and Subjectivity. Berkeley: University of California, 226241.

Krug, Etienne, et.al. 2002. World Report on Violence and Health. Geneva: World Health Organization.

Lase, Formas Juitan. 2015. “Böwöö, Böli Gana'a, dan Depresiasi “Nilai” Perempuan', Nias Bangkit, 16 Mei. Diakses dari http://nias-bangkit.com/2015/05/bowo-boli-ganaadan-depresiasi-nilai-perempuan/.

Lubis, Misran. 2011. "Penelitian Kekerasan terhadap Anak Perempuan dan Pernikahan Dini di Pulau Nias", dokumen Pusat Kajian dan Perlindungan Anak (PKPA) Nias. Diakses dari http://konsillsm.or.id/kekerasan-terhadap-anak-perempuanpernikahan-dini-di-pulau-nias/?lang=en

Suharto, Edi. Tanpa Tahun. "Metode dan Teknik Pemetaan Sosial". Diakses dari http://www.policy.hu/suharto/modul_a/makindo_18.htm.

World Health Organization. 2013. Global and regional estimates of violence against women: prevalence and health effects of intimate partner violence and non- 
partner sexual violence. Diakses dari

http://www.who.int/reproductivehealth/publications/violence/97892415646 25/en/. 